\title{
Factors affecting Customer Retention in the Restaurant Industry: Moderating Role of Restaurant Location
}

\author{
Ammar Ahmed \\ Assistant Professor, Department of Management Sciences, MNS-UET, Multan \\ Sanober Salman Shaikh \\ Institute of Business Administration, University of Sindh Jamshoro, Pakistan \\ Rafat Naseer \\ MSBA, Institute of Southern Punjab Multan \\ Muhammad Asadullah \\ Assistant Education Officer, School Education Department Punjab
}

\begin{abstract}
This study investigated the main effects of service quality and price fairness on customer retention. The study also investigated the moderating role of restaurant location in service quality, price fairness-customer retention relationships. Data collected from 182 customers visiting selected restaurants located in Multan city of Pakistan. The collected data relates to the chosen variables i.e. service quality, price fairness, restaurant location, and customer retention. The significant positive results of linear regression analysis revealed that service quality, price fairness and restaurant location predicted the customer retention. The results of step-wise multiple regression analysis revealed that restaurant location positively moderated the relationship of service quality and customer retention. It also revealed that restaurant location positively moderated the relationship of price fairness and customer retention. This study may have practical implications for human resource managers regarding recruitment decisions. It may have importance for restaurant managers or owners regarding quality of service and pricing plans which are true reflection of the services provided. Similarly, they may give due consideration to the location factor while launching a food service business. On the basis of the findings of the study, conclusions have been made and recommendations and directions for further research have been offered.
\end{abstract}

Keywords: Service Quality, Price Fairness, Restaurant Location, Customer Retention

\footnotetext{
1. ammar.malik419@gmail.com

2.rsanobershaikh25@yahoo.com

3.rafat.naseer@hotmail.com

4.asadmpa@gmail.com
}

Page 95 
IBT Journal of Business Studies (IBT-JBS) Volume 15 Issue 2 December 2019

\section{INTRODUCTION}

In this era of globalization, organizations make possible efforts to remain competitive and maximize their profit by satisfying and retaining their customers. Research suggests that customer loyalty is predicted by the quality of service along with other factors (Tan, Oriade, \& Fallon, 2014). Moreover, service quality not only predicts customer satisfaction, it is also a contributing factor in customer retention and customer loyalty (Loyyl \& Kumar, 2018; Venetis \& Ghauri, 2004). Research suggests that service organizations succeed in retaining their customer because of their service quality factor. Due to service excellence, customers pay visit to get their service again and again irrespective of the price increase. When organizations succeed in making their customers realized that they are receiving best in lieu of their money, their loyalty increases (Lai, 2015; Al-Tit, 2015). Similarly, studies revealed that price fairness is strongly predicts customer retention in general and especially in especially in food and hotel industry (Hanaysha, 2016). Organizations prefer fair prices to retain customer instead of constantly losing them as customers prefer better quality services at affordable prices (Dawes, 2009). As Dawes (2009) argued that price raise is detrimental to the customer retention and their loyalty and they may switch to another service provider. Thus it is safe to argue that along with service quality, loyalty and retention of customer is also predicted by the pricing mechanism. Fair prices may increase customer retention while frequent price increase may adversely affect the loyalty. Another contributing factor in customer retention in hotel industry includes the physical location of a restaurant. Research suggests that easy access of a restaurant located at visible place helps for retaining customer and the strategic success of restaurant (Hanaysha, 2016).

Service quality refers to the conformance to the requirements of customers and is related to the customer satisfaction (Venetis \& Ghauri, 2004). It involves overall excellence of services (Omar, Ariffin, \& Ahmad, 2016)that strongly predicts both satisfaction and retention of customers. All the tangible and intangible factors shaping the level of customer retention constitute service quality (Al-Tit, 2015). Parasuraman, Zeithaml, \& Berry(1988)coined five major domains of service quality which are tangibles, reliability, responsiveness, assurance and empathy.

The choice of location in which a restaurant/hotel operates is considered as strong predictor of future success. Research suggests that without having a better location for a hotel or restaurant, factors like service quality, price fairness and expert management may prove ineffective (Parsa, Gregory, \& Terry, 2011). The location of the restaurants may be selected by keeping in view the geographic, demographic and even psychographic factors. Key characteristics of an ideal location for a restaurant or hotel include easy approachable access, volume, total number of people residing in the locality, volume of competition and the financial position of the population (Hanaysha, 2016).

Price is the most vital factor in marketing mix (4 Ps of marketing) as it is the direct source of return on investment (ROI). Business managers and marketing executive adopt pricing strategies which not only are the source of ROI but also are in-line with the financial position of the customer. Research suggests that fair pricing 
strategy is strong predictor of satisfaction of customer and their retention in general and especially in hotel industry. Prices that are true reflection of service quality are linked with customer retention (Hanaysha, 2016).

Organizations strive for customer retention and loyalty to maximize their profit. Customer retention refers to the efforts of organization to make the customer loyal. It involves customers' favorable attitudes towards repurchase and revisit intentions. (Kaura, Prasad, \& Sharma, 2015).

Researchers have been investigating service quality in broader area of marketing during the last three decades. Moreover, they have been studying contributors that may affect the loyalty and retention of customer. However, we find weaker evidences of scholarly work on the association of SQ and CR in general and especially in hotel/ food industry (Ahmad, Khuwaja, Othman, Qureshi, \& Ali, 2017; Venetis \& Ghauri, 2004). Further, Ahmad et al. (2017) argue that relationship need investigation in Pakistani context. Similarly, Andaleeb \& Conway (2006) argued that the context in which a restaurant operates may be of vital concern for the customer. However, weaker evidence of studies have been found while investigating these relationships (Hanaysha, 2016; Andaleeb \& Conway, 2006).

The hotel and restaurant industry in wolrd and espeically in Pakistan is rapidly growing and has a share of $2.3 \%$ in the national economy. The state is striving to improve hotel industry in the country by provinding best quality services to the customers (Hashim, Hashim, Bo, Ahmad, \& Mobin, 2016). The establishment of Pakistan Tourism Development Corporation (PTDC) is marked step in this reagrd. PTDC has established motels in almost every recreational city of the country. These motels offers quality services and affordable prices to the national and international tourists. Further, privately hotels and restauarnts also offers their services to the tourists. However, tourists have been complaining about the substandard services and unfair prices. To ensure quality of food, Punjab Food Authority (PFA)is taking corrective steps. It has made certain corrective action during the last decade. Heavy fines have been imposed on the hotels and restaurants because of poor food quality. Price Control Committees (PCC) have also taken steps to ensure implementation of approved prices. The hotel and restaurant managers are also concious in this regard. This shows that service and food quality in the country and especially in Punjab province has been given attention and the natter has beeb prioritised. Irrespective of such marked initiatives, it is imperative to get the restaurant managers realized the legal demands of state regarding quality and price fairness. Further, as it has been found from the literature that location of the restaurant is contributing factor towards customer retention, due considerations may be given to location while launching a restaurant (Saleem \& Raja, 2014).

In view of the above, it is quite clear that there exists research defict in the area of customer retention regarding its relation with service quality, price fairness and location of restaurant. Moreover, the studies have separately invetsigated the relationships of these variables with customer retention. However, we found no evidence where these variables have been modelf together. Furthermore, moderating role of location in service quality, price and customer retention relationship is also 
missing in marketing literature. Thus, the current study was aimed at invetsigating the moderating role of location in service quality, price and customer retention relationship in restaurants.

\section{THEORETICAL BACKGROUND AND HYPOTHESES DEVELOPMENT}

\section{Customer Retention (CR) and Service Quality (SQ)}

Research on the relationship of SQ and CR during the last decade suggests that customer retention is largely predicted by the SQ offered by a service organization (Al-Tit, 2015). Further, it has also been found that SQ is the most vital factor for retaining the customers as compared any other factor of customer retention. Past experiences of customer regarding the quality of service shape the revisit and repurchase intentions of the customers. If the customers feel that service quality offered by the firm is not reflected in price, it may hurt the revisit intentions and thus may negatively affect the retention (Loyyl \& Kumar, 2018).Nguyen et al. (2018), Ryu \& Lee (2017), Chua, Lee, \& Han(2016)assert that SQ and CR are positively associated with each other. Khan, Hussain, \& Yaqoob(2013) supported these findings in Pakistani restaurant industry perspectives. They found that service quality enhances brand loyalty and customer retention. Restaurants offering best quality services succeed in establishing good relationships with customer and retaining them as well. The findings of this study are very significant as these are also a base for the theoretical foundations of the current study supporting customer retention and service quality relationship in restaurant industry in Pakistan. It was revealed that customer retention predicts the return on investment (ROl) of firm which in turn increases the profitability of the restaurant.

Wu \& Mohi(2015) argue that there is common belief among customers that they visit a restaurant keeping in mind the service quality, fair prices and better physical environment. They further argue that there is an array of factors that may affect the retention of the customers. Factors like price and brand image act as mediators between service quality and customer retention. Studies of Hana \& Hyunb (2017), Hanaysha (2016) further suggest that location of a restaurant may also mediate the relationship between service quality and customer retention. Qin, Prybutok, \& Zhao(2012) conducted a study on service quality at fast-food restaurants in China. The results of the study revealed that service quality at a restaurant strongly predicts customer retention. The study further revealed that other factors like corporate image, fair prices and perceived value also affect customer loyalty and repurchase intentions. On the other hand, substandard quality with unjust pricing may negatively affect customer loyalty.

However, study conducted by $\mathrm{Hu}$, Kandampully \& Juwaheer (2009) revealed that there exists no direct relationship between service quality and customer retention. Instead, it is mediated through factors like corporate image and fair prices. However, these findings are contradictory to the findings of the study conducted by Al-Tit(2015) who state that service quality has a direct relationship on customer retention. Studies in other sectors such as banking and telecom sector operating in UK and UAE revealed that customer repurchase or revisit intentions are affected by the corporate image of the organization, market share and pricing strategies. Study 
of Ahmed \& Othman(2017) revealed that organizations need to offer best customer services to remain competitive in the market. Contrary to it, Rothenberger(2015) found a positive and significant relationship between customer satisfaction, customer retention and service quality in hospital industry. Similarly, study conducted by Venetis \& Ghauri(2004) revealed customer affection or loyalty is predicted by the quality of service offered by an organization. Study further revealed that due to service quality, customer retention is affected which in turn affect the return on investment and profitability of an organization.

Although (Ahmed et al. 2017) investigated the influence of SQ on CR and revisit intentions in FMCGs in Pakistan. The findings of the study revealed that SQ and $\mathrm{CR}$ are predicted by the quality of service of FMCGs. The study further indicated that service quality has positive effect on customer revisit intentions. They argue that the service quality not only affects level of satisfaction of customer, it also enhances customers' affiliations with the firm (Ammar Ahmed \& Othman, 2016). Earlier, Ali et al. (2010) found that the broader objective of any business firm is to make the customers satisfied which in turn results in making them loyalty to the firm. This objective is achieved through offering better service quality coupled with fair prices and brand image. Study of Venetis \& Ghauri(2004) offered interesting findings regarding the relationship of SQ and CR. Results revealed that not only affects customers' retention, it also plays a pivotal role shaping overall image of the firm and positive words of mouth or recommendations. In view of the above results, this study hypothesizes that:

\section{H1: Service quality positively affects customer retention.}

\section{Price Fairness (PF) and Customer Retention}

Fair pricing strategy is regarded as the most vital factor in retaining customers in any business. From food industry perspectives, it decides the customers' intentions to revist a restauarnt. Research suggests that customers feel satisfied with the services of a restaurant if fair prices are charged while unfair prices adversely affect the revist intentions of the customers(Hana \& Hyunb, 2017). Dawes (2009) conducted a study to investigated the effects of prices increase on customer retention. It was found that if prices reflect the services offered to customers at restaurant, they feel sense of belonging to loyalty to the hotel. Study conducted by Voon (2017) on service environment of restaurants revealed that fairly charged prices and peaceful environment of restaurants were strong predictors of satisfaction of customers and hence customers' retention. Similarly, Hanaysha(2016)investigated factors of customers' retention in fast food restaurant industry. The study revealed that price fairness is strong predictor of CR in fast food restaurant and hotel industry.

Fair prices help in retaining customers while price raise is detrimental to the customer retention and their loyalty. The results of the study are consistent with the findings of the study conducted by Hassan, Hassan, Nawaz, \& Aksel(2013) who found that along with other factors, price fairness is strong predictor of customers' retention. The results of the study are also consistent with the findings of the study conducted by Xia, Monroe, \& $\operatorname{Cox}(2004)$. They found that fair prices attract customers and also help in retaining them. Rothenberger (2015) investigated 
the success factors of restaurant. The results of the study depicted that transparent pricing were regarded as the most significant factor for success of a restaurant. Hence, it is safe to hypothesize that;

\section{H2: Price fairness positively affects customer retention.}

\section{Restaurant Location (RL) and Customer Retention}

The site of a restaurant is also important factor that contribute to customer rention and revisit intentions. Studies revealed that restaurants operating at visible places, having vast parking, ventilated and clean physical environment attract the customers and further positively affects their revisit intentions (Minai \& Lucky, 2011). The study conducted by Voon (2017) revealed that both the factors collectively contribute the customer retention as fair pricess could hardly attract customers if the physical surrounding of the restaurant is poor.Hanaysha(2016) investigated the determinants of CR in fast food restaurant industry. The study revealed that accessibility and visibility of a restaurant are vital factor for retaining customer and the strategic success of restaurant. Hence, it is safe to hypothesize that;

\section{H3: Restaurant location positively affects customer retention.}

\section{Moderating Role of Restaurant Location}

The researchers established a new relationship between moderator and independent and dependent variables which is a common practice in humanities and social sciences. A moderator defines the nature of relationship between independent and dependent variables (Baron \& David, 1986). The current study employed a two paths model to contribute to the results. In one path, restaurant location is used as moderator between the SQ and CR and in second path; restaurant location is used as moderator between the PF and CR.

The motivation behind the investigation of the proposed model has been taken from the studies of (Voon, 2017); Ahmad et al. (2017); Hanaysha (2016); Al-Tit (2016); Lai (2015) \& Parsa et al., 2015). These studies described a positive impact of restaurant's location on quality of service and retention of customers. Similarly, the literature also suggests that restaurant location positively affects the relationship between fairly charged prices and retention of customer. Hence, in view of the significant relationship between service quality, price fairness, restaurant location and customer retention, the research postulated that restaurant location moderates the relationship of SQ and PF with CR. From the above literature, the relationships can be hypothesized that:

\section{H4: Restaurant location moderates between service quality and customer retention relationship. \\ H5: Restaurant location moderates between price fairness and customer retention relationship.}

\section{Research Frame Work}

Studies conducted by researchers like Al-Tit (2016), Lai (2015), Parsa et al. (2015) and Hanaysha (2016), are some of the rationale that instigate the researcher to study 
the relationship in restaurant industry of Pakistan. This paper involved a total of four variables i.e. two independent variables, (Service Quality, Price Fairness), one dependent variable (Customer Retention) and one moderating variable (Restaurant Location). As shown in research framework (see Appendix A), it is assumed that quality of service and fairly charged prices positively affect the customer retention in restaurant industry of Pakistan. It is also assumed that restaurant location positively affects customer retention in restaurant industry of Pakistan. Further, it is assumed that restaurant location moderates service quality, price fairness and customer retention relationship in restaurant industry of Pakistan.

\section{Methods}

\section{Sampling and Collection of Data}

Data were sought from customers visiting five selected restaurants located in Multan city of Pakistan using a self-administered questionnaire. The researchers assured the respondents that confidentiality of the data will be ensured. Self-report measures containing items related to Service Quality, Price Fairness, Restaurant Location and Customer Retention were completed by the respondents. Moreover, the questionnaires also sought demographic information of respondents. These demographics include gender, age, marital status and employment. The researcher distributed 250 questionnaires among the respondent questionnaires. However, 182 complete questionnaires were received back giving a response rate of $73 \%$ which is common in similar studies.

\section{Measures}

The researchers used self-report measures to measure the variables understudy by seeking responses of the participants on a 5 point Likert-type scale. Quantification of responses was made as strongly disagree $=1$, disagree $=2$, Neutral $=3$, agree $=4$ \&strongly agree $=5$.

\section{Service Quality}

The five facets of service quality were measured using a 28 items scale developed and used by Tan, Oriade, \& Fallon(2014). The reliability of the service quality scale is 0.81 which is good for such studies.

\section{Price Fairness}

Price fairness was measured through a 4 items scales adopted from Hassan, Hassan, Nawaz, \& Aksel(2013) and used by Hanaysha(2016). The reliability of the price fairness scale is 0.73 .

\section{Restaurant Location}

Restaurant location was measured by 5 items scale adopted from Minai \& Lucky(2011) and used by Hanaysha(2016). The reliability of the price fairness scale is 0.75 which is good for such studies.

\section{Customer Retention}

Customer retention was measured by 4 items scale adopted from Ammaria \& Bilgihan (2017). The reliability of the price fairness scale is 0.78

Page $\mid 101$ 


\section{Data Analysis}

The researchers presented some of the major findings of the study made on basis of these results. Descriptive data analysis involves the frequency, mean scores and percentage while inferential analysis involves correlation \& regression analysis of the main as well moderation effects.

The table of correlation analysis (see Appendix B) shows that SQ, PF and RL were significantly and positively related to CR. The results also show that SQ, PF and RL were also significantly and positively related with each other.

\section{Moderated Regression Analysis}

The researchers applied Linear Regression Model to predict the value of the dependent variable 'Customer Retention' on the basis of independent variables Service Quality, Price Fairness and Restaurant Location. Further, moderating effect of restaurant location (RL) in service quality (SQ), price fairness (PF) and customer retention (CR) relation was tested by Stepwise Multiple Regression Model.

All the main effect hypotheses were tested through multiple linear regression analysis. Table 2 (see Appendix B) presents the results of regression analysis for main effects of independent variables on dependent variable. The researchers entered gender in the first step while at second step all the independent variables were entered for main effects.

Results depicted that SQ and CR were positively related to each other $(\beta=0.28$, $\mathrm{p}<0.05$ ) supporting the first hypothesis.

The results depicted a positive relationship of PF and CR $(\beta=0.19, p<0.05)$ supporting the second hypothesis.

It has also been found that $R L$ is positively related to $C R(\beta=0.19, p<0.05)$ supporting the third hypothesis.

The fourth and fifth hypotheses were tested by applying moderated regression analysis (Cohen et al. 2003). The researchers entered the independent variables as well as moderator for this purpose while at first step we entered gender as control variable. Further, second step involved entering independent variables as well as moderator. The third step involved entering of interaction terms of moderators and independent variables (service quality $\times$ restaurant location) and (price fairness $\times$ restaurant location). It was believed that significant relationship of product terms may confirm moderation.

Table 2 clearly depicts that product term of service quality $\times$ restaurant location was significant for customer retention $(\beta=0.17, p<0.05)$. The relationship of SQ and CR was moderated by RL supporting the fourth hypothesis.

Moreover, the interaction term of price fairness $\times$ restaurant location was significant for customer retention $(\beta=0.18, \mathrm{p}<0.05)$. Restaurant location moderated the relationship price fairness and customer retention. Therefore hypothesis H5 was 
supported.

\section{DISCUSSION}

The results of linear regression analysis revealed that CR is predicted by SQ in restaurants industry of Pakistan. It was found that $28 \%$ of the variance in Customer Retention can be accounted because of Service Quality of the restaurant. Similar results were found by Loyyl \& Kumar(2018) who found that CR is strongly predicted by SQ. Moreover, Venetis \& Ghauri(2004) found similar results. Moreover, linear regression analysis revealed that price fairness is strong predictor of customer retention in restaurants industry of Pakistan. It was found that 19\%\% of the variance in Customer Retention can be accounted because of price fairness at the restaurant. The findings of the current study are consistent with the findings of the study conducted by Hanaysha(2016). He found that Fair prices help in retaining customers while price raise is detrimental to the customer retention and their loyalty. Similarly, Lai (2015) and Al-Tit (2015) found similar results. They found that organizations succeed in making their customers realized that they are receiving best in lieu of their money, their loyalty increases. Thus it can be safely argued that fair prices positively affect customer retention in restaurant industry. The results of linear regression analysis further revealed that RL is strong predictor of CR in restaurants industry of Pakistan. It was found that $19 \% \%$ of the variance in Customer Retention can be accounted because of restaurant location. The findings of the current study are consistent with the findings of the study conducted by Hanaysha(2016). He found that easy approach of a visible restaurant was vital factor for retaining customer and the strategic success of restaurant. Thus it can be safely argued that restaurant location positively affects customer retention in restaurant industry. The results of stepwise multiple regression analysis revealed that restaurant's location moderates the SQ, PF, CR relationship.

\section{CONCLUSIONS}

The study adds handful knowledge in the area of sales and marketing as well as human resource management in general and especially in four variables understudy. The results of Pearson's Correlation analysis revealed significant positive relationship between independent variables i.e. service quality, price fairness and restaurant location and dependent variable i.e. customer retention. Further, the results of stepwise multiple regression analysis revealed that restaurant location moderated the relationship of service quality and customer retention. It also revealed that restaurant location moderated the relationship of price fairness and customer retention in restaurant industry.

\section{IMPLICATIONS}

The study may have implications for entrepreneurs, policy makers and business managers engaged in restaurant and hotel business. Study revealed that customer retention is predicted by service quality in restaurants industry of Pakistan. This suggests that the management of restaurants operating in the country may focus on improving the service quality. They must ensure the quality of service covering Page | 103 
all the dimensions of it i.e. responsiveness, assurance and empathy, tangibles, reliability, food quality and cleanliness of the dining area. In view of the legal requirement of food and safety of customers, service quality must be ensured. Since it has been found from the study that service quality is predictor of customer retention, the study may have implications for human resource managers as well. The human resource managers of restaurants may give due importance to factors such as responsiveness and empathy of staff while making recruitment decisions. Prospected employees having empathy may be hired as they may quickly and wise respond to the needs of customers.Another important finding of the study includes the role of restaurant location which strongly predicted customer retention. In view of the importance of the location, the business persons and entrepreneurs may give due importance to the location while starting a restaurant business. The location may be easily approachable with good physical environment and having wider parking facility. The study revealed that price fairness is also a strong predictor of customer retention in restaurant industry. Prices may be charged in view of the service offered to the customers. The restaurant managers or owners may devise pricing plans which are true reflection of the services provided.

\section{LIMITATIONS AND RECOMMENDATIONS}

As the study employed self-report measures to seek the responses of the respondents on the variables understudy, it may cause response bias. Future studies may use performance measures to avoid the issue of biasness. The respondents of the study were the customers of restaurants who reported about the variables understudy. They may show their personal grievances towards a specific restaurant. It is therefore suggested to replicate the study by taking business managers and entrepreneurs as the population of the study. The study employed quantitative design to undertake the investigation in restaurant industry; its results may hardly be generalized to any other business setting. It is therefore suggested that a qualitative design may be employed to seek the personal opinions of the respondents.

\section{REFERENCES}

Ahmed, A., Khuwaja, F. M., Othman, I. B. L., Qureshi, M. A., \& Ali, R. A. (2017). Validation of SERVQUAL Model in Relation to Customer Loyalty: Evidence from FMCGs in Pakistan. Sukkur IBA Journal of Management and Business, 4(2), 54-76.

Ahmed, A., \& bin Lebai Othman, I. (2017). The impact of strategic attributes on organizational Performance in Pakistan Banking Sector: A Review and Suggestions for Future Research. International Journal of Academic Research in Business and Social Sciences, 7(8), 2222-6990.

Al-Tit, A. A. (2015). The effect of service and food quality on customer satisfaction and hence customer retention. Asian Social Science, 11(23), 129.

Ammar Ahmed, P. M. D. I. L. O., \& Othman, M. D. I. L. (2016). Mediating Role of Customer Commitment on Customer Loyalty in FMCG. Scholars Journal of Economics, Business and Management, 3(5), 263-270.

Andaleeb, S. S., \& Conway, C. (2006). Customer Satisfaction in the Restaurant Industry: An Examination of the Transaction-Specific Model. Journal of 
Services Marketing ,20(1) pp.3-11.

Bahri-Ammari, N., \& Bilgihan, A. (2017). The effects of distributive, procedural, and interactional justice on customer retention: An empirical investigation in the mobile telecom industry in Tunisia. Journal of Retailing and Consumer Services, 37, 89-100.

Baron, R. M., \& Kenny, D. A. (1986). The Moderator-Mediator Distinction in Social Psychological Research: Conceptual, Strategic and Statistical Considerations. Journal of Personality and Social Psychology , 51(6), 1173-1182.

Chua, B., Lee, S., \& Han, H. (2016). Consequences of cruise line involvement: acomparison of first-time and repeat passengers. Int. J. Contemp. Hosp. Manage, 29(6), pp.1658-1683.

Dawes, J. (2009). The Effect of Service Price Increases on Customer Retention: The Moderating Role of Customer Tenure and Relationship Breadth. Journal of Service Research , 11(3), 232-245.

Few, S. (2012, January/Feburary/March). Use-Based Types of Quantitative Display. Visual Business Intelligence Newsletter, pp. 1-4.

Hana, H., \& Hyunb, S. S. (2017). Impact of Hotel-Restaurant Image and Quality of Physical Environment, Service, and Food on Satisfaction and Intention. International Journal of Hospitality Management , 63, 82-92.

Hanaysha, J. (2016). Restaurant Location and Price Fairness as Key Determinants of Brand Equity: A Study on Fast Food Restaurant Industry. Business and Economic Research , 6(1), 310-323.

Hashim, I., Hashim, S., Bo, X. Y., Ahmad, M., \& Mobin, M. (2016). Empirical Analysis of Pakistan Hotel Industry based on SWOT Model. Journal Tourism, Hospitality abd Sports , 19, 17-24.

Hassan, M., Hassan, S., Nawaz, M. S., \& Aksel, I. (2013). Measuring Customer Satisfaction and Loyalty Through Service Fairness, Service Quality and Price Fairness Perception: An empirical Study of Pakistan Mobile Telecommunication Sector. Journal Science International , 25(4), 971-980.

Kaura, V., Prasad, C. S., \& Sharma, S. (2015). Service quality, service convenience, price and fairness,customer loyalty, and the mediating role of customer satisfaction. International Journal of Bank Marketing, 33(4), 404-422.

Khan, S., Hussain, S., \& Yaqoob, F. (2013). Determinants of customer satisfaction in fast food industry a study of fast food restaurants Peshawar Pakistan. Studia commercialia Bratislavensia, 6(21), 56-65.

Lai, I. K. (2015). The Roles of Value, Satisfaction and Committment on the effect of Service Quality on Customer Loyalty in Hong Kong - Style Tea Restaurants. Cornell Hospitality Quarterly, 56(1), 118-138.

Loyyl, B. W., \& Kumar, M. (2018). A Critical analysis on Service Quality and Customer Retention, 66(1), 1-15.

Minai, M. S., \& Lucky, E. O. (2011). The Moderating Effect of Location on Small Firm Performance: Empirical Evidence. International Journal of Business and Management , 6(10), 178-192.

Nguyen, Q., Nisar, T. M., Knox, D., \& Prabhakar, G. P. (2018). Understanding Customer Satisfaction in the UK Quick Service Restaurant Industry: The Influence of the Tangible Attributes of Perceived Service Quality. British Food Journal , 121(11), pp.2620-2636.

Omar, M. S., Ariffin, H. F., \& Ahmad, R. (2016). Service Quality, Customers'

Page $\mid 105$ 
Satisfaction and the Moderating Effects of Gender: A Study of Arabic Restaurants. Procedia - Social and Behavioral Sciences, 224, 384-392.

Parasuraman, A., Zeithaml, V. A., \& Berry, L. L. (1988). SERVQUAL: MultipleItem Scale for Measuring Consumer Perceptions of Service Quality. Journal of Retailing, 64(1), 12.

Parsa, H. G., Gregory, A., \& Terry, M. (2011). Why do restaurants fail? Part III: An analysis of macro and micro factors.

Parsa, H. G., van der Rest, J. P. I., Smith, S. R., Parsa, R. A., \& Bujisic, M. (2015). Why restaurants fail? Part IV: The relationship between restaurant failures and demographic factors. Cornell Hospitality Quarterly, 56(1), 80-90.

Qin, H., Prybutok, V., \& Zhao, Q. (2012). Perceived Service Quality in Fast-food Restaurants: Empirical Evidence from China. International Journal Quality \& Reliability Management, 27(4), 424-437.

Rothenberger, S. (2015). Fairness through transparency: The influence of price transparency on consumer perceptions of price fairness. Working Papers CEB, 15 .

Ryu, K., \& Lee, J. (2017). Examining restaurant quality, relationship benefits, andcustomer reciprocity from the perspective of relationship marketinginvestments. J. Hosp. Tourism Res. , 41(1), 66-92.

Saleem, H., \& Raja, N. S. (2014). The Impact of Service Quality on Customer Satisfaction, Customer Loyalty and Brand Image: Evidence from Hotel Industry of Pakistan . Middle East Journal of Scientific Research , 19(5), 706-711.

Tan, Q., Oriade, A., \& Fallon, P. (2014). Service quality and customer satisfaction in Chinese fast food sector: A proposal for CFFRSERV. Advances in Hospitality and Tourism Research (AHTR), 2(1), 30-53.

Venetis, K. A., \& Ghauri, P. N. (2004). Service Quality and Customer Retention: Building Long-term Relationships. European Journal of Marketing , 38(11/12), 1577-1598.

Voon, B. H. (2017). Service Environment of Restaurants: Findings from the youth customers. Journal of ASIAN Behavioural Studies , 2(2), 67-77.

Wu, H. C., \& Mohi, Z. (2015). Assessment of Service Quality in the Fast-Food Restaurant. Journal of Food Service Business Research ,18(4), 358-388.

Xia, L., Monroe, K. B., \& Cox, J. L. (2004). The price is unfair! A conceptual framework of price fairness perceptions. Journal of Marketing, 68(4), 1-15.

Zikmmund, W., Babin, B., Carr, J., \& Griffin, M. (2012). Business Resaerch Methods (9th ed.). Mason: Cengage Learning. 
IBT Journal of Business Studies (IBT-JBS) Volume 15 Issue 2 December 2019

\section{APPENDIX A}

\section{Service Quality}

1. Assurance \& Empathy

2. Cleanliness

3. Food Quality

4. Reliability

5. Responsiveness

6. Tangibles

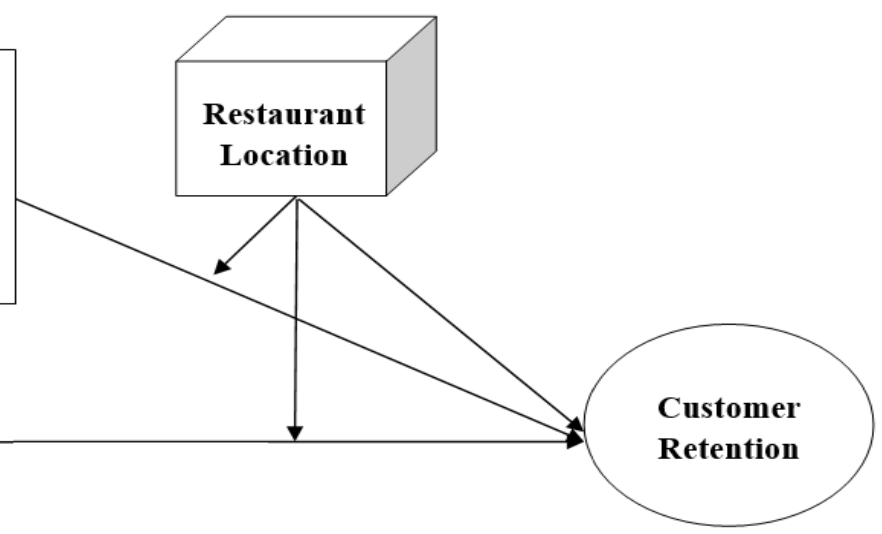

Figure 1: $\underline{\text { Research Framework }}$

APPENDIX B

\begin{tabular}{|l|l|l|l|l|l|l|l|l|l|l|}
\hline & Mean & SD & 1 & 2 & 3 & 4 & 5 & 6 & 7 & \\
\hline Gender & 1.30 & 0.46 & - & & & & & & & \\
\hline Age & 1.87 & 0.52 & -0.13 & - & & & & & & \\
\hline Employment & 2.64 & 0.70 & -0.02 & $0.26^{* *}$ & -0.13 & - & & & & \\
\hline $\begin{array}{l}\text { Service } \\
\text { Quality }\end{array}$ & 3.94 & 0.49 & 0.10 & 0.12 & -0.06 & $(0.81)$ & - & & & \\
\hline $\begin{array}{l}\text { Price } \\
\text { Fairness }\end{array}$ & 2.92 & 0.64 & -0.02 & 0.05 & -0.02 & -0.05 & $0.18^{*}$ & $(0.73)$ & - & \\
\hline $\begin{array}{l}\text { Customer } \\
\text { Retention }\end{array}$ & 3.08 & 0.57 & 0.07 & 0.11 & -0.14 & -0.04 & $0.32^{\star *}$ & $0.64^{* *}$ & $(0.75)$ & - \\
\hline $\begin{array}{l}\text { Restaurant } \\
\text { Location }\end{array}$ & 2.82 & 0.93 & -0.01 & -0.18 & $0.19^{* *}$ & $-0.19^{* *}$ & $-0.21^{* *}$ & $-0.17^{\star *}$ & $0.61^{\star *}$ & $(0.78)$ \\
\hline
\end{tabular}

Significance level at 0.01 
IBT Journal of Business Studies (IBT-JBS) Volume 15 Issue 2 December 2019

Table 2: Step-wise Regression Analysis including Moderated Results

\begin{tabular}{|l|l|l|}
\hline & \multicolumn{2}{|c|}{ Customer Retention } \\
\hline & \multicolumn{1}{|c|}{$\beta$} & \multicolumn{1}{|c|}{$\Delta \mathrm{R} 2$} \\
\hline Step 1 & & \\
\hline Gender & 0.02 & 0.00 \\
\hline Step 2 & & \\
\hline Service Quality (A) & $0.28^{* * *}$ & \\
\hline Price Fairness (B) & $0.19^{*}$ & \\
\hline Restaurant Location (c) & $0.19^{* *}$ & $0.12^{\star * *}$ \\
\hline Step 3 & & \\
\hline A $\times$ C & & \\
\hline B $\times$ C & $0.17^{*}$ & \\
\hline
\end{tabular}

